\title{
iSANTRI FOR KYAI GALANG SEWU ISLAMIC BOARDING SCHOOL
}

\author{
Dyah Arumsari* \& Lydia Christiani*
}

*Library Science Study Program, Diponegoro University

Email:dyaharumsari03@gmail.com, lydia.christiani@live.ac.id

(Submitted: 23-07-2021, Revised: 01-11-2021, Accepted: 24-11-2021)

DOI: $10.24252 / v 9 \mathrm{i} 2 \mathrm{a} 1$

\begin{abstract}
ABSTRAK: Penelitian ini mendiskusikan persepsi santri Kyai Galang Sewu terhadap aplikasi iSantri. Penelitian kualitatif ini menggunakan pendekatan studi kasus. Tujuh informan dipilih dengan menggunakan teknik purposive sampling di mana mereka semua pengguna iSantri. Data dikumpulkan melalui observasi, interview, dan kajian literatur. Penelitian ini menemukan bahwa santri menerima dengan baik aplikasi iSantri. Mereka menggunakannya untuk meningkatkan pengetahuan mereka tentang Islam, menjadi bahan untuk menginterpretasikan buku-buku Islam, dan juga sebagai sumber alternatif belajar. Tahapan penerimaan aplikasi iSantri didasarkan pada penggunaan aplikasi iSantri oleh para santri sebagai media penunjang proses pembelajaran. Aplikasi iSantri memberikan kemudahan akses tanpa harus menunggu lama untuk mendapatkan informasi buku-buku agama Islam. Kegunaan dan kemudahan akses aplikasi iSantri mendorong munculnya niat dan sikap para santri untuk terus menggunakan aplikasi iSantri.
\end{abstract}

Kata kunci: iSantri; ebooks; koleksi Islam; technology acceptance model (TAM)

ABSTRACT: This study discusses the perception of the iSantri application by the santri from the Kyai Galang Sewu Islamic Boarding School. The research method used in this research is descriptive qualitative with a case study approach. Informants were obtained through purposive sampling with seven informants using the iSantri application at the Kyai Galang Sewu Islamic Boarding School. Data collection techniques used were observation, interviews, and document study. The results of this study indicate that the perception of the iSantri application is well received by the santri to increase their knowledge of Islam, make it easier to interpret Islamic religious books, get additional references for interpretation and complete the meaning of Islamic religious books, and also as an alternative source of learning at the Kyai Galang Sewu Islamic Boarding School. The stages of accepting the iSantri application are based on the use of the iSantri application by the santri of the Kyai Galang Sewu Islamic Boarding School who use the iSantri application as a medium to support the learning process. The iSantri application provides easy access without having to wait so long to get information on Islamic religious books. The usefulness and ease of access to the iSantri application encourage the emergence of the intention and attitude of the santri to continue using the iSantri application.

Keywords: iSantri application; ebooks; Islamic collections; technology acceptance model (TAM)

\section{INTRODUCTION}

Almost all human activities cannot be separated from the help of information technology. This makes information technology continues to develop from time to time to form new innovations. A technological innovation is not only made in certain fields, but is comprehensive in all fields. 
This is because one's needs are increasingly complex and must be supported by fast-paced things. In this case, technology has a fairly high existence in supporting human work, one of which is education. Both general education and education held based on special curriculum content, such as the religious curriculum in Islamic boarding schools.

Based on Hayati's opinion (in Syafe'i, 2017) Islamic boarding school is an educational institution in the form of a dormitory under the leadership of a kiai (a priest man) who lives together with santri (students) as a big family in pesantren (Islamic boarding school) by studying Islamic teachings in depth. Currently, there are many leaders of Islamic boarding schools who are literate in information technology and make boarding schools more open to technology to take advantage of learning innovations that can be obtained from anywhere.

The leader of the Depok Al-Hikmah Islamic Boarding School, Arif Zamhari, said that a boarding school also requires a touch of technology so that it can produce religious abilities and can keep up-to-date with technological developments well in line with the glory of society (Republican, 2014). The developments in the world of pesantren education today are still traditional depending on the decisions of the kiai who lead them. However, there have been many who have carried out reforms both by the community and the government as additional provisions for the students to be able to participate in competing in the modern era without reducing the noble character of the Islamic boarding school in accordance with the objectives of the Islamic boarding school (Shofiyyah, Ali, \& Sastraatmadja, 2019).

Modern Islamic boarding schools that are currently known to the public are not only located in the city center, but are also located in rural areas and participate in utilizing existing access to information technology. One of the Islamic boarding schools that has provided easy access to information technology is Kyai Galang Sewu Islamic boarding school. Along with its development, the boarding school experienced many changes in the learning system from using printed reference books to digital ones. The school has been around for a long time since 1999 until now, it is very strategically located with the lecture campus, so the majority of the students are students from the nearest campus.

Currently, modern the santri have been facilitated by open internet access, which is expected to support in gaining insight and knowledge because the existence of information technology in the santri environment can help them in digital literacy. The Ministry of Religion of the Republic of Indonesia has even provided innovative facilities in the form of a handheld library application to access social media-based e-bookstores and e-Pustaka, namely the iSantri application. The iSantri application contains digital books made specifically for the millennial santri community who want to add insight or learn with digital books.

The curriculum system at the Kyai Galang Sewu Islamic boarding school leads to book learning with various grade levels and different versions. The learning patterns of their students are still enjoyed to using printed books, but access to digital books online is also recommended by ustadz (teacher) on the condition that the books used and read have clear sources and can increase faith and help students in the process of studying Islam.

Based on several resources that discuss the perception of digital library applications in the field of special education institutions such as in Islamic boarding schools, it is rare and raised in a study. The discussion that is often raised is precisely in the field of digital library studies with a big scope of education. Therefore, this study conducted research focusing on the iSantri application which is released by the Ministry of Religion of the Republic of Indonesia as a breakthrough that offered effectiveness in accessing learning resources, so that the learning system in Islamic boarding schools might be better, especially in the modern era like now. Even though it still requires efforts to be accepted and used as best as possible by the students to learn and increase their knowledge.

Kyai Galang Sewu Islamic boarding school has facilitated the openness of access to information technology is facilitated in the learning system. The santri (students) can use 
smartphones without certain restrictions except during prayer and the reading Qur'an times arrive. Apart from outside these times, the students are free to use any learning support applications, including the iSantri digital library application. Thus, this is the main interesting for the authors to examine how the perception of students about the application

\section{PREVIOUS FINDINGS}

Pesantrens are currently experiencing many challenges. In the big challenges, they are required to improve the learning environment. Meanwhile, in small-scale challenges, they are required to be able to rearrange the learning interactions between kiai and santri, with the concept of education currently used and in the future. Through the challenges, it must be responded positively to seeing the changes in the times that are increasing, it cannot be denied that one of them is in the field of education that utilizes information technology (Iryana, 2015).

The existence of renewal that occurs from time to time, especially in Islamic boarding schools causes changes that are very influential in the curriculum system being taught. At this time many have implemented open access education in Islamic boarding schools, which means that the students are free to access information technology inside and outside the schools with no special restrictions to access and some are even given facilities to easily utilize technology. According to Mukhibat \& Ghafar (2019), in their research that there are characteristics of Islamic boarding schools that have fully used access to technology to advance their education environment. For example, Pondok Pesantren Al Hikam Malang accepts all students of various ages by developing learning methods through the website alhikam.ac.id which contains learning materials.

The curriculum system that usually characterizes the ease of access to technology is the type of modern or semi-modern pesantren which has started by adapting through an open pesantren education curriculum (Partners \& Ahmad, 2017). An open educational curriculum can increase the number of Islamic boarding schools that are literate in information and communication technology (Sholihah, 2012).

An agency can achieve success in making information technology systems is the acceptance of the technology to the users. Utilizing information technology systems is not only used by general students but can also be used by students to be used as learning media or digital references. Creating an information technology system needs to study further, whether something that has been made can be accepted and utilized as best as possible by its users. According to Jogiyanto (2008) (in Kurniasari \& Priambada, 2018) Technology Acceptance Model (TAM) developed by Davis (1986) is a model of acceptance of information technology systems used by users in several versions of the model level.

The final version of the development of the Technology Acceptance Model (TAM) was conducted by Venkatesh and Bala in 2008. The model is the development of an integrated technology acceptance model known as Technology Acceptance Model 3 (TAM 3). It uses four different variables including individual differences, system characteristics, social influences, and facility conditions which are determinants of the usability perceived by system users (Lai, 2017). The Technology Acceptance Model 3 (TAM 3) version explains in more detail how to use an information system. 


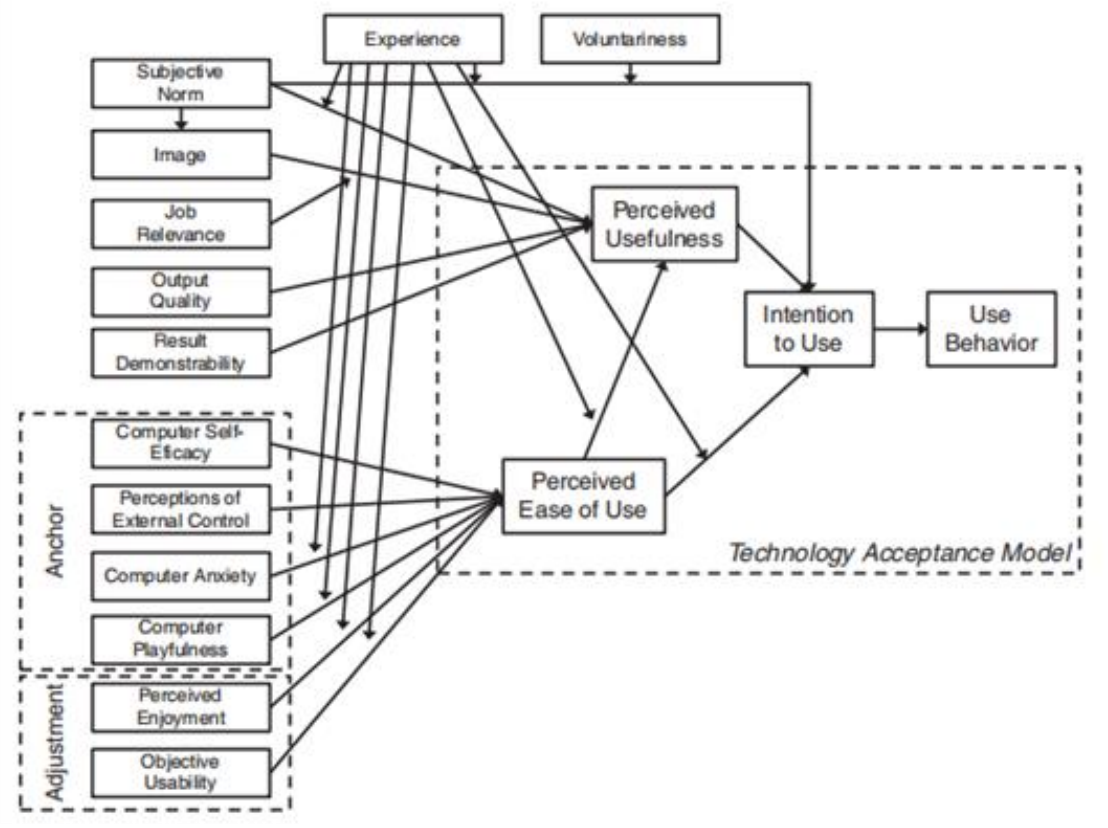

Figure 1. Technology Acceptance Model 3 (TAM 3)

TAM 3, according to Venkatesh (2008) describes an important chart of the concept of individual use of an information technology system through users' experiences, as follows:

\section{1) Perceived usefulness}

Is a statement of the user's perception of the usefulness of the technology system that is used according to his needs or not. Through the perception of usefulness, a person can get positive things with his experience in using technology application systems with proven results.

\section{2) Perceived ease of use}

One's perception is that the technology system used is easy to understand and practice in everyday life, there is no burdensome thing, able to control it well. How easy or difficult an information system can be used.

\section{3) Intention when using the system (intention to use)}

A person will use a certain technology if he has the first intention to use it and try it out whether a system that will be used can have a positive impact and benefit if he uses it. This can be related to the perceived usefulness and ease of forming individual intentions to use a system.

\section{4) Attitude when using the system (use behavior)}

It is a user's attitude towards the use of a technology system, whether it will be accepted or rejected for various reasons that exist through moderation by an individual's experience.

Thus, TAM 3 can explain the perception of acceptance of the information technology usage through users' experiences either an individual or a group of community of the current generation with perceptions of usefulness, convenience, intentions, and attitudes. Technology Acceptance Model 3 has been tested in real-world IT implementation settings.

\section{RESEARCH METHODOLOGY}

This study used qualitative research methods with a case study approach. Qualitative research has descriptive characteristics in the form of written and spoken words from people who are observed in certain conditions, nature, and findings that emphasize meaning that is tied to values (Siyoto, 2015). The study used primary sources and secondary sources. The primary sources were gathered through interviews and observations with Kyai Galang Sewu Islamic Boarding School's 
students. The informants in this study were selected through the purposive sampling technique where Sugiyono (2016) states that purposive sampling is a technique for determining research samples with certain criteria that are considered by the objectives of the research conducted. From the interview, the study has chosen seven informants who met the criteria and used the iSantri application for some time. These informants were selected based on the length of staying at Kyai Galang Sewu Islamic Boarding School and have experiences with the iSantri application. Furthermore, based on the level of education, namely from groups, students, and also students who have worked. Where students from different educational groups will be able to see the type of book needed in the iSantri application that they use. The secondary data were collected through document studies. The data were then analyzed using the Miles and Huberman data analysis model which consisted of three stages, namely data reduction, data presentation, and conclusion.

\section{RESULTS AND FINDINGS}

Kyai Galang Sewu Islamic Boarding School, as mentioned before, allows their students to bring cellphones or laptops to be used properly in finding information references while studying at the school or in the field of general education. Information technology is freely accessible to students who need it within the school. The iSantri application is used by some students to increase their knowledge in the field of religious science. Santris prefer other alternatives due to the lack of facilities provided in their dormitory, reference books are also very minimal due to the Covid-19 pandemic, libraries and laboratories are temporarily closed, thus requiring students to be able to find learning reference sources independently. One interview says that "In this digital era, especially during a pandemic like this, the iSantri application helps me to learn books or read books without having to carry a lot of books and printed books." (Dzunu, February 18, 2021 at 08.00 WIB).

Kyai Galang Sewu Islamic Boarding School's students are required to be able to complete interpreting the book before the exam period. Thus, the right solution for some students is to use the iSantri application, with a fast-working system plus complete books with various versions. There are many digital books references in the iSantri application such as in the field of Islam, kitab kuning (yellow books), hadith, Sufism, and other Islamic reading books in the field of history and self-motivation that can be used to increase knowledge. An interview, "The books provided from the iSantri application helped me a little in searching for further books from those provided by the school from the basic to advanced levels, such as Hadith learning", (an interview on December 13, 2020).

The reason students used the iSantri application is that when learning through printed books, the students feel that the explanation is incomplete, so then they decide to use the application as an appropriate reading recommendation to complete the meaning of the book. According to a study that there were so many students in Indonesia who prefer digital books rather than printed ones. It is in line with what Maulida said in an interview, one of the respondents, that "usually when studying through printed books the explanation is incomplete, so sometimes try to look for it from the iSantri application to complete the meaning of an empty book", (an interview on December 28, 2020). Other students also used the iSantri application for learning references during their study. 


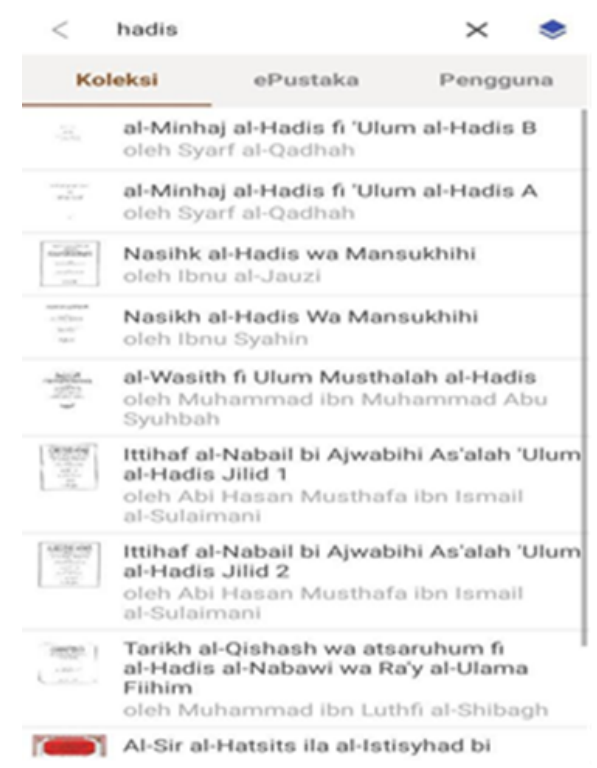

Figure 2. Types of iSantri Application Collection

According to Sinta, "I came to know that the Ministry of Religion created an application to facilitate Indonesian students in studying at Islamic boarding schools. So, I am interested to use the application. I can read useful and motivating books to increase my faith" (an interview on December 13, 2020).

Not all santris have used the iSantri application because of various factors. For example, certain books did not exist in the application. Thus, some prefer to use Google, the easiest media to use in finding information. Most also challenge with a technical issue, like what a respondent says, "No, because my cellphone memory is full and I don't need it" (an interview on February 21, 2020). Downloading the iSantri application requires a lot of memory space, the internet must be strong to read digital books in the application. In such issues, some prefer Google as an alternative media. The ease and difficulty of using information technology systems are two important things for students in utilizing technology to obtain information that is needed. According to Jogiyanto (2009, p.36), the application should be quite simple, its structure and use can be understood and the procedure is easy to follow.

The iSantri application is measured based on the theory of the Technology Acceptance Model (TAM). The procedure for using the iSantri application makes it easy for students to display the features in which it is user-friendly and show the collections presented and other menus that can be used and utilized properly. This application has adapted to the times with digitalization which makes it easy to access such as a virtual library without having to remove burdensome materials or things, and because it is an online application so it can be accessed anywhere and anytime when needed.

Based on the interview document studies, it was explained that some of the Kyai Galang Sewu Islamic Boarding School's students received the application well and some did not fully accept it because the use factor had not been carried out optimally. The various factors why the students used it because of usefulness, convenience, intention, and attitude in using the iSantri application, all these perceptions will be described through.

\section{The usefulness of the iSantri Application}

The assumption is that an information technology used by the students provides various significant benefits in supporting the learning process of the students at the Kyai Galang Sewu Islamic Boarding School where by using the application the students gained more knowledge, 
have a lot of references that can support knowledge about Islamic religious understandings, relevant in their field and can increase the effectiveness of the students to continue learning and reading through the books taught in the Kyai Galang Sewu Islamic Boarding School as well as books outside the boarding school.

The iSantri application can provide more benefits to make it easier for students to get other sources of information apart from the boarding school they are in, students can also learn other disciplines with various versions and reading references that have never been taught without having to spend a lot of money.

According to Davis (1989) (in Fatmawati, 2015), a system can provide good performance in someone who uses it. A system will be used if it provides meaningful use, otherwise if a system does not provide usefulness, it will not be used by the user. So, if an information system is useful for its users, it will automatically be utilized and give its own impact. The iSantri application which is specifically presented for students to be accepted and used. The students can read appropriate readings and readings outside of their dormitory to increase knowledge about the existing books as said in the interview that, "My knowledge increases. In the iSantri, I found a complete lesson, for example about how to pray correctly and how to read it. Furthermore, there are readings that are rarely and never even explained by the the teachers in this dormitory" (Maulida, 28 December 2020 at $10.00 \mathrm{WIB})$.

According to Davis in Fathurrahman (2017), it indicates that someone believes that a technology system can improve performance in the activities carried out. The iSantri application is used by students may increase their knowledge of the Islamic religion, of course with references to reading books that can be accessed quickly without taking a long time to look for them. Apart from the perception of usefulness in using the application, the students also feel the ease of using the iSantri application in understanding daily books.

\section{Ease of Use of the iSantri Application}

In addition to the iSantri application providing useful aspects for students, the iSantri application also provides convenience in the learning process at the Kyai Galang Sewu Islamic Boarding School. The information presented is complete and clear, among others, easy to learn, and it can increase productivity in searching for information and collections as new knowledge in supporting the learning process, and for some students can get information faster.

This is reinforced by an interview with Shobikhati that, "The iSantri application is very helpful in making it easier to find information or collections to support learning at this dormitory because the free fees can be accessed via smartphones so there is no need to spend money to buy books again, so the money can be used for other needs", (Shobikhati, January 17, 2021 at 14.00 WIB).

The iSantri application is an alternative for students to get references with attractive screen design and full of pictures, as stated by Dzunu that, "Yes, it is very easy and fast-access and you don't have to wait long" (Dzunu, 18 February 2021 at 08.00 WIB). The average time needed to search for collections in the iSantri application varies as explained by Shobikhati that, "The time I use to access the iSantri application is relatively fast" (January 2021 at 14.00 WIB).

According to the informants, accessing the iSantri application to obtain appropriate information is relatively fast, only takes fifteen minutes if the signal is stable and depends on the reading material to be searched. Through this, the iSantri application accelerates the work of students to obtain information. Therefore, it will lead to further intention to use it and believe that the technology system used is easy to learn and practice in everyday life without anything burdensome (Fatmawati, 2015). 
Intentions of the Kyai Galang Sewu Islamic Boarding School Santri when using the iSantri application

The end-users have intention and interest to use the iSantri application since the initial launch of the iSantri application. The students have their own character and intentions in using information technology. Some are really to increase knowledge, look for references, some are just trying. According to the interview with Shobikhati that, "Initially I wanted to read Islamic books published by the Salaf lodges, especially books on Sufism because there are very few references to Sufism books here, it our library here or incomplete" (Shobikhati, January 17, 2021 at 14.00 WIB).

It shows that students are interested in using the iSantri application because it can make it easier for their learning interests and provided many books of Sufism presented in it. The intention of the students was proven when using the iSantri application patiently and remained productive to add to the list of readings that were only few religious books in their school library, such what Maulida said that she has the intention and willingness to learn from the application, "To add to my reading material while studying at the dormitory and study religion because the iSantri application is really suitable" (Maulida, 28 December 2020 at 10.00 WIB).

The perception of students in using the iSantri application raises the usefulness and convenience of users which results in the intention to use the application further. This is in line with Jogiyanto (2008) in Kurniasari \& Priambada (2018) which suggested that if someone has the intention to use an information system, it will definitely lead to an attitude tendency in its use. The santris of the Kyai Galang Sewu Islamic Boarding School have indicated it.

\section{CONCLUSION}

The user's attitude towards the iSantri application is something that can be used as an evaluation of how the perceptions of the students after using the iSantri application for various reasons. Through iSantri, the students can find out that the Ministry of Religion has a digital book application to make it easier for them to access relevant information it needs. In creating this application, the Ministry of Religion in collaboration with PT. Maya Script, so that application development becomes more structured.

However, tt is hoped that the iSantri application can help students meet their information needs, especially to support the learning process at the Kiai Galang Sewu Islamic Boarding School, as stated from an informant that, "Hopefully in the future the presentation in the iSantri application is better and not as complicated as this because you have to register first to read books and not go out alone while reading" (Bintan, 23 January 2021 at 20.00 WIB). In addition, information speed factors, effectiveness and time efficiency when accessing such application are considered by the end-users as an informant said, "Information speed, effectiveness and time efficiency must be cosidered." (Dzunu, February 18, 2021 at 08.00 WIB).

The ease of use of the iSantri application is felt by its users to have a strong correlation with speed, effectiveness, and time efficiency in obtaining information, where this is also related to the quality of the internet network as stated by the following informant Maulida, "Mudah Sis. But sometimes if the signalWifi(red. Wireless Fidelity) is bad, the application closes itself and the screen goes white. Sometimes I've also experienced logging out myself, so I have to sign in to my original account again to be able to use the app." (Maulida, 28 December 2020 at $10.00 \mathrm{WIB}$ ). The attitude shown by students using the iSantri application can be seen that students tend to need the iSantri application to assist in finding advanced book references to support the learning process at the Kyai Galang Sewu Islamic Boarding School. The students chose to continue using the iSantri application. The attitude shown by students produces positive behavior that appears when using the iSantri application (Chutur, 2009).

It can be concluded that the iSantri application was accepted well in the Kyai Galang Sewu Islamic Boarding School. It comes with attractive packaging and a fairly complete collection of books, making students interested in using it to access information faster. It is used by the santris 
to increase understanding about Islam, make it easier to interpret the book, get additional references for tafsahi, complete the meaning of the book that is still empty, and as an alternative learning resource that supports learning at school.

\section{REFERENCES}

Chutur, M. (2009). Overview of the Technology Acceptance Model: Origins, Developments and Future Directions. Sprouts: Working Papers on Information Systems, 9(37). https://www.researchgate.net/publication/277766395\%0AOverview

Fathurrahman, M. (2017). Analysis Of Acceptance of The Ijogja Mobile Application by Library Using the Technology Acceptance Model Approach in Grhatama Pustaka, Balai Services, Bpad Diy Library. http://digilib.uin-suka.ac.id/27486/

Fatmawati, E. (2015). Technology Acceptance Model (TAM) for Analyzing Acceptance of Library $\begin{array}{llll}\text { Information } & \text { Systems. } & \text { Iqra } & \text { Journal, }\end{array}$ https://garuda.ristekbrin.go.id/documents/detail/437893

Iryana, W. (2015). Challenges of Salaf Islamic Boarding Schools in the Modern Era. Educational $\begin{array}{lll}\text { and } \quad \text { Islamic } & \text { Studies, }\end{array}$ http://ejournal.kopertais4.or.id/mataraman/index.php/murabbi/article/view/426

Kurniasari, P., \& Priambada, S. (2018). Analysis of Perception of Usefulness and Perception. EASY. Business Administration, 58(2), 129-136. http://administrasibisnis.studentjournal.ub.ac.id/index.php/jab/article/viewFile/243 $9 / 2835$

Lai, P. (2017). the Literature Review of Technology Adoption Models and Theories for the Novelty Technology. Journal of Information Systems and Technology Management, 14(1), 21-38. https://doi.org/10.4301/s1807-17752017000100002

Partners \& Ahmad. (2017). Islamic Boarding School EDUCATION RENEWAL. https://ejournal.iainkerinci.ac.id/index.php/islamika/article/view/207

Mukhibat, M., \& Ghafar, M. (2019). Virtual pesantren: New trend of Islamic education model in Indonesia. International Journal of Innovation, Creativity and Change, 5(2), 105-117. https://ijicc.net/images/Vol5iss2_/8_Mukhibat_P105_2019_R2.pdf

republica. (2014). It's time for Islamic boarding schools to be technology literate. July 25. https://www.republika.co.id/berita/koran/education-koran/14/07/25/n99a4523saatnya-pesantren-melek-technology

Shofiyyah, NA, Ali, H., \& Sastraatmadja, N. (2019). Islamic Boarding School Model in the Millennial Era. BELAJEA: Journal of Islamic Education, 4(1), 1. https://doi.org/10.29240/belajea.v4i1.585

Sholihah, U. (2012). The Role of ICT in the Modernization of Islamic Boarding Schools. Scholar: $\begin{array}{llll}\text { Journal of Education and } & \text { Society, }\end{array}$ https://doi.org/10.21154/cendekia.v10i1.399

Siyoto, S. (2015). Basic Research Methodology (Ayup, Ed.). https://docplayer.info/48670324Dasar-metodologi-penelitian-dr-sandu-siyoto-skm-m-kes-m-ali-sodik-ma.html

Sugiyono. (2016). Quantitative, Qualitative, and R\&D Research Methods. Bandung: Alphabeta.

Syafe'i, I. (2017). PONDOK PESANTREN: Character Building Education Institutions. Al$\begin{array}{llll}\text { Tadzkiyyah: Journal of Islamic Education, } & 8(1),\end{array}$ https://doi.org/10.24042/atjpi.v8i1.2097

Venkatesh, V. (2008). Technology Acceptance Model 3 and a Research Agenda on Interventions. 39(2), 273-315. https://doi.org/10.1111/j.1540-5915.2008.00192.Lai, P. (2017). the Literature Review of Technology Adoption Models and Theories for the Novelty Technology. Journal of Information Systems and Technology Management, 14(1), 21-38. https://doi.org/10.4301/s1807-17752017000100002 